\title{
STUDIES ON THE RISKS ASSOCIATED WITH THE USE OF PARATHION-IMPREGNATED GAUZE STRIPS IN FLY CONTROL
}

\author{
BY \\ JON GLÖMME and Å. SWENSSON \\ From the Department of Occupational Medicine, Karolinska Hospital, and the King Gustaf V Research Institute, \\ Stockholm
}

(RECEIVED FOR PUBLICATION DECEMBER 18, 1956)

Organic phosphorus compounds are being increasingly used as insecticides. They are the most effective of all substances tested and the tendency of insects to develop resistance to them appears to be very small in comparison with that developed to such insecticides as the halogenated hydrocarbons.

The main disadvantage of most organic phosphorus insecticides is their high toxicity for warmblooded animals and human beings, whom they affect by inactivating the enzyme cholinesterase. Some of these substances seem, moreover, to be capable of inflicting nerve damage which may or may not be connected with the cholinesterase inactivation (Bidstrup, Bonnell, and Beckett, 1953; Barnes and Denz, 1953; Fenton, 1955; Durham, Gaines, and Hayes, 1956).

Organic phosphorus compounds are used as insecticides in agriculture and horticulture, and are applied as aerosols in order to produce a knockdown effect. Attempts have also been made to use the " systemic " effect of these compounds by causing them to be taken up into plants in order to destroy insects feeding thereon. Organic phosphorus compounds have also been applied as residual insecticides, for example, in fly control. Thus experiments have been made in placing parathion-impregnated gauze strips in stables and cowsheds, which proved remarkably effective (Wichmand, 1953; Glömme and Swensson, 1955). Parathion is diethyl-paranitrophenylthiophosphate. Similar applications have been tested elsewhere (Maier and Mathis, 1955; Kilpatrick and Schoof, 1956). We have carried out a field investigation and laboratory experiments with animals in order to determine whether the last procedure may endanger the health of the workers.

\section{The Impregnated Gauze Strips}

The use of parathion-impregnated gauze strips under the roof in stables and cowsheds to combat flies was introduced in Denmark in 1952 (Wichmand, 1953). The flies, settling on the strips, come into direct contact with the parathion and rapidly die. As parathion evaporates very slowly, the insecticidal effect of the strips persists for at least five to six months. The method is effective and is widely used in the Scandinavian countries.

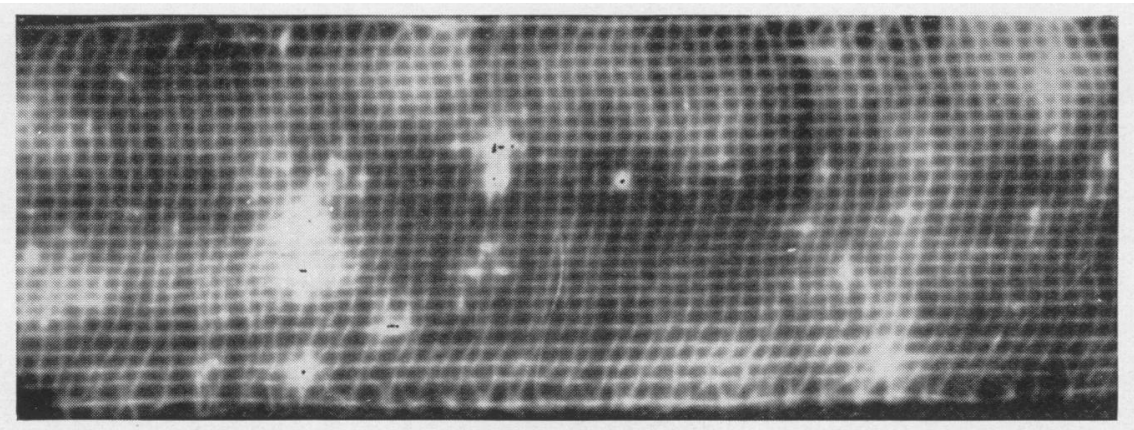

FIG. 1.-Autoradiogram of gauze strip impregnated in the usual way with parathion containing radioactive phosphorus. 
The strips of gauze are soaked in a solution of technical parathion in such a way that every square metre contains about $3 \mathrm{~g}$. of parathion. The technical product is not pure, but contains small quantities of certain other substances having a similar biological effect, e.g., various S-isomers and paraoxon (where sulphur is replaced by oxygen) and the decomposition product p-nitrophenol, which has no effect on cholinesterase.

The distribution of the parathion is not uniform throughout the strip. Fig. 1 shows an autoradiogram of a strip which has been impregnated in the usual way with parathion containing radioactive phosphorus $\left(\mathrm{P}^{32}\right)$.

The strips are sold in hermetically sealed packets, and are placed under the roof in stables and cowsheds. On the packet there is a notice stating that protective gloves should be worn when mounting the strips, that the packet and any unused strips should be destroyed immediately after use, and that the strips are highly poisonous to animals and human beings. The strips must not be used in human habitations.

The manufacturers recommend the use of 1 square metre of the strips (containing about $3 \mathrm{~g}$. of parathion) to every 30 square metres of roof surface.

The use of gauze strips is superior to the indiscriminate application of parathion powder on beams and windowsills.

\section{Control Methods}

As organic phosphorus insecticides inactivate cholinesterase (ChE) in warm-blooded animals and as this inactivation varies with the quantity of insecticide absorbed, it is possible to determine the degree of exposure by ascertaining the $\mathrm{ChE}$ activity in various tissues. For practical clinical work determination in blood is used.

Repeated exposure to and absorption of small quantities of the insecticide leads to a cumulative effect, as recovery of $\mathrm{ChE}$ after each exposure is slow, but variable.

Of the various methods which have been given for determining the $\mathrm{ChE}$ in blood, we used the gasometric technique in the modification described by Augustinsson (1948). In this method the acid formed in the enzyme reaction is taken up into a bicarbonate system, and an equivalent quantity of $\mathrm{CO}_{2}$ is released and recorded as the volume of $\mathrm{CO}_{2}$ (in $\mu 1$ ) which is formed in $30 \mathrm{~min}$.

It is assumed that there are two different groups of cholinesterases. One group, the acetylcholinesterases $(\mathrm{AChE})$, are characterized by the fact that they break down acetylcholine more rapidly than other esters.
Acetylcholinesterase occurs mainly in the erythrocytes and in the brain. The second group, the butyrylcholinesterases (BChE), are characterized by their capacity to break down butyrylcholin, $\mathrm{BChE}$, which is thought to be formed in the liver, and occurs mainly in blood plasma. The BChE activity in the plasma is lowered in certain liver diseases. In the literature $\mathrm{AChE}$ is often called "true cholinesterase" and BChE " pseudocholinesterase".

In our investigations we used acetyl- $\beta$-methylcholine in the substrate for determining AChE activity and butyrylcholine for determining BChE activity. The lowering of BChE activity in plasma generally occurs first and is strongest. The AChE activity of the erythrocytes is affected later and falls more slowly.

The method has been made more suitable for field investigations by a modification of the blood tests which has been worked out by Augustinsson and Heimbürger (1953).

Exactly $0.05 \mathrm{ml}$. of blood is taken up in a pipette and applied in a thin layer on filter paper.

The paper used is a filter paper in general laboratory use, Munktell No. 3. Other papers of good laboratory quality may be used as well, e.g., the Whatman papers. The paper is allowed to dry in the air and is then mailed to the laboratory. If kept cool it can be preserved for several months without affecting the result of the analyses. In the laboratory the whole blood spot containing a known amount of blood (in the general procedure $0.05 \mathrm{ml}$.) is cut in small pieces with a pair of scissors and put directly into the main compartment of a Warburg flask. Ringer's bicarbonate solution is then added. The material is extracted for half an hour. This method has the advantage that the investigations can be centralized and the results are therefore more consistent and reliable.

\section{Field Investigations}

Before allowing the use of parathion-impregnated gauze strips in Sweden the authorities gave special permission for certain tests to be carried out. An investigation of a group of farm-workers employed in the cowsheds where the strips were being tested was therefore made in 1954.

For this investigation 43 cowsheds of different types and sizes in central Sweden were selected and the tests were undertaken during the months of May and June.

TABLE 1

NORMAL VALUES OF CHOLINESTERASE ACTIVITY IN BLOOD (AUGUSTINSSON, 1955) AND PRESENT FIELD INVESTIGATION USING THE SAME METHOD

\begin{tabular}{|c|c|c|c|c|c|c|}
\hline & \multicolumn{3}{|c|}{$\begin{array}{c}\text { Cholinesterase Activity } \\
\text { in Erythrocytes } \\
\text { (AChE) }\end{array}$} & \multicolumn{3}{|c|}{$\begin{array}{c}\text { Cholinesterase Activity } \\
\text { in Plasma } \\
\text { (BChE) }\end{array}$} \\
\hline & $\begin{array}{c}\text { Mean } \\
\left(\mu 1 \mathrm{CO}_{2} / 30 \mathrm{~min} .\right)\end{array}$ & $\begin{array}{l}\text { Standard } \\
\text { Deviation }\end{array}$ & $\begin{array}{l}\text { Number of } \\
\text { Observations }\end{array}$ & $\begin{array}{c}\text { Mean } \\
\left(\mu 1 \mathrm{CO}_{2} / 30 \mathrm{~min} .\right)\end{array}$ & $\begin{array}{l}\text { Standard } \\
\text { Deviation }\end{array}$ & $\begin{array}{c}\text { Number of } \\
\text { Observations }\end{array}$ \\
\hline $\begin{array}{l}\text { From Augustinsson* } \\
\text { Initial value in field investigation }\end{array}$ & $\begin{array}{l}35 \cdot 4 \\
34 \cdot 0\end{array}$ & $\begin{array}{l}4 \cdot 7 \\
3 \cdot 5\end{array}$ & $\begin{array}{r}300 \\
43\end{array}$ & $\begin{array}{l}75 \cdot 5 \\
80 \cdot 2\end{array}$ & $\begin{array}{l}14 \cdot 7 \\
17 \cdot 8\end{array}$ & $\begin{array}{r}294 \\
43\end{array}$ \\
\hline
\end{tabular}

*Augustinsson's values are based on 300 and 294 estimations on samples from 141 and 116 individuals respectively. 
The farmworkers concerned were examined before the strips were installed and again one week, and in some cases one month, after the strips had been applied. A general medical examination and determination of the ChE activity in the blood were undertaken.

In the general examination it emerged that some workers had felt ill or had had a headache after the application of the impregnated gauze strips. No objective signs and no diminution of BChE activity were, however, established.

Acetylcholinesterase and BChE activity show considerable variations between different individuals (Augustinsson, 1955). Augustinsson's results are given in Table 1 together with the absolute activity values for our group, consisting of male cowhands aged 17-65 years. In view of the considerable individual differences in cholinesterase activity it is preferable to use a determination made on the same individual as a baseline before exposure. Even with the same individual, however, there may be variations (Augustinsson, 1955) which must be taken into account when assessing isolated values.

TABLE 2

DETERMINATION OF CHOLINESTERASE ACTIVITY IN BLOOD OF EMPLOYEES WORKING IN LOCATIONS WHERE PARATHION-IMPREGNATED GAUZE STRIPS HAD BEEN

\begin{tabular}{l|c|c|c}
\multicolumn{3}{c}{ APPLIED (MAY AND JUNE, 1954) } \\
\hline & $\begin{array}{c}\text { Number of } \\
\text { Employees } \\
\text { Examined }\end{array}$ & $\begin{array}{c}\text { Cholinesterase Activity as \% } \\
\text { Activity before Application } \\
\text { of Strips }\end{array}$ \\
\cline { 2 - 4 } & & $\begin{array}{c}\text { Erythrocytes } \\
\text { (AChE) }\end{array}$ & $\begin{array}{c}\text { Plasma } \\
\text { (BChE) }\end{array}$ \\
\hline $\begin{array}{l}\text { Before application } \\
\text { One week after } \\
\text { application after } \\
\begin{array}{c}\text { One month after } \\
\text { application }\end{array}\end{array}$ & 43 & $100 \pm 1.6$ & $\begin{array}{c}100 \pm 3.5 \\
101 \pm 1.4\end{array}$ \\
\hline
\end{tabular}

In Table 2 the average values for the AChE and $\mathrm{BChE}$ activity have been expressed as a percentage

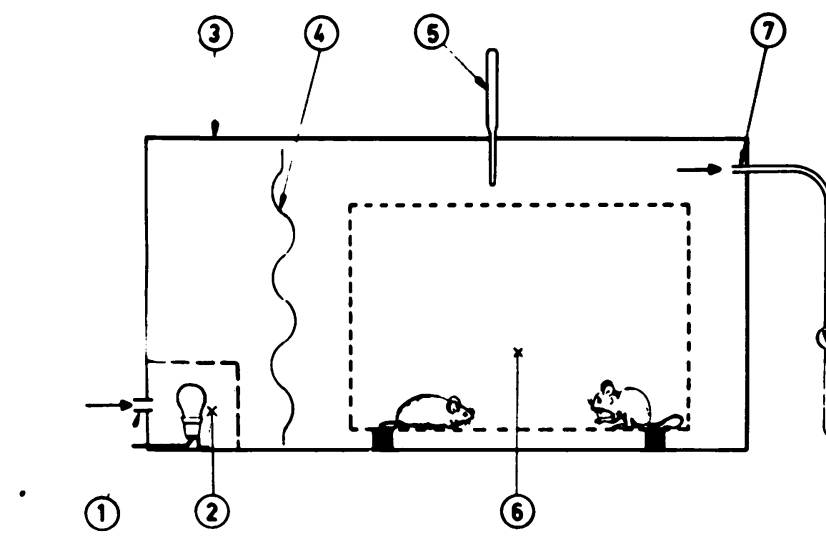

of the value determined before application of the strips. The activity of $\mathrm{ChE}$ was not reduced during a period of one month after the strips had been applied. This is probably due to the insignificant evaporation of the parathion and to the fact that in the technical parathion used the content of related substances with greater volatility was small, and to the fact that the ventilation in the cowsheds was good, being estimated at an average of 10 to 20 air changes per hour.

\section{Experimental Investigations}

For the experiments with animals guinea-pigs were used, in simple exposure chambers (Fig. 2), in which the temperature and ventilation could be varied. In these chambers were placed commercial parathion-impregnated gauze strips said to contain $3 \mathrm{~g}$. of parathion per square metre. One-third of a square metre of impregnated gauze was used to every square metre of floor surface, i.e., about 10 times as much as is recommended for combating flies in stables and cowsheds. The parathion content of the strips was estimated and found to vary from 2.5 to $3.1 \mathrm{~g}$. per square metre. The ventilation was varied between 0.5 and 2.5 air changes per hour. The temperature in some experiments was maintained at 25 to $26^{\circ} \mathrm{C}$. and in others at 30 to $32^{\circ} \mathrm{C}$.

Attempts to determine the concentration of parathion in the exposure chamber by absorption in ethanol or caustic soda were unsuccessful.

Blood samples to determine ChE activity were taken by cardiac puncture without anaesthesia before the experiment, after three and seven days' exposure and, in some experiments, weekly up to six weeks' exposure. Usually only the BChE activity was determined, as this is high in guinea-

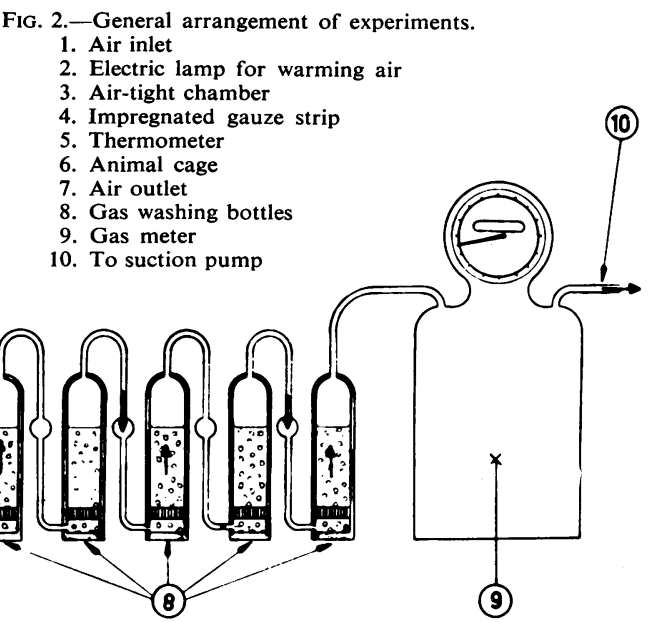



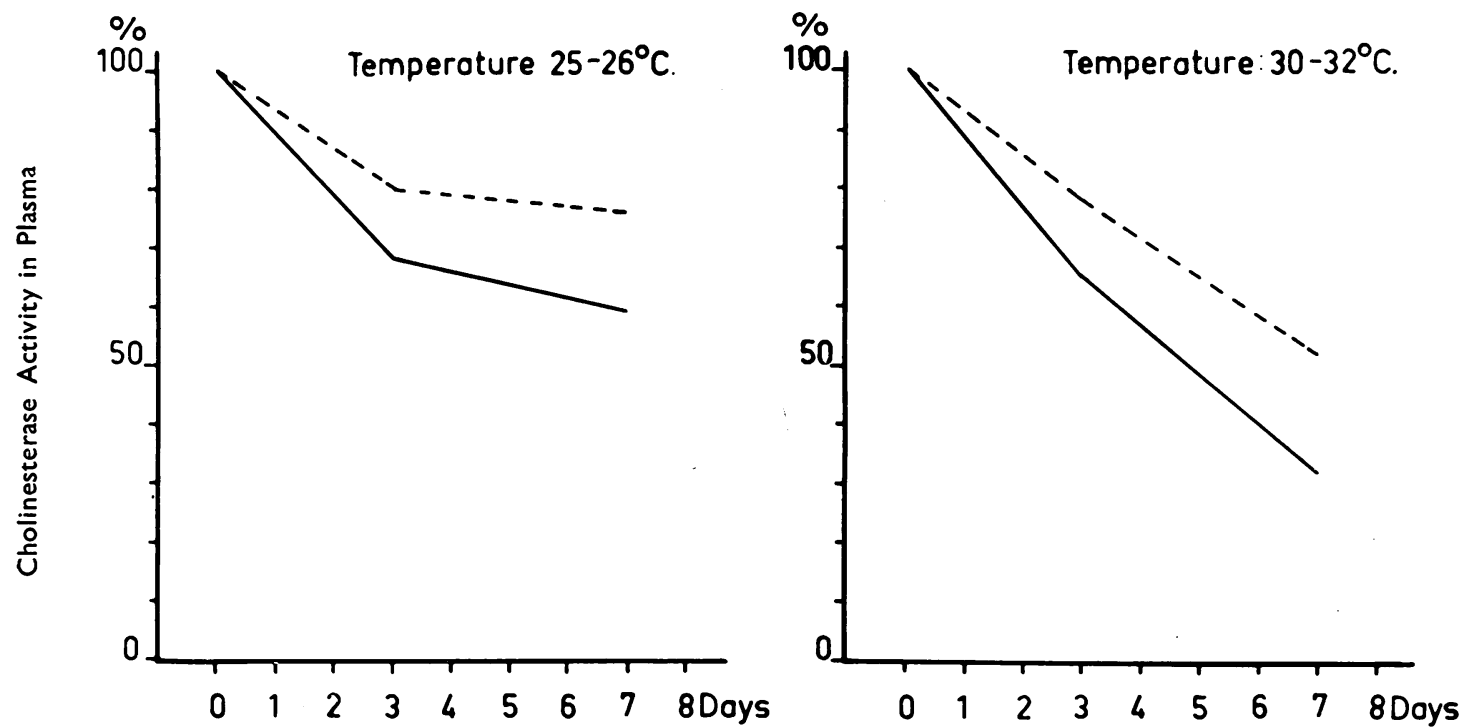

FIG. 3.-Effect on plasma cholinesterase activity (BChE) of continuous exposure in the experimental chamber at different temperatures and ventilations.

Solid line represents 0.5-1.2 air changes per hour, and dotted line 1·5-2.5 air changes per hour.

pigs. The AChE activity in the erythrocytes of guinea-pigs is low and the assessment of changes as a sign of exposure is therefore somewhat more uncertain. Both the experience of others and our own studies show that the effect of parathion on $\mathrm{AChE}$ and on BChE activity is essentially similar, but $\mathrm{BChE}$ activity reacts more quickly.

In guinea-pigs, as in human beings, considerable variations in $\mathrm{BChE}$ activity are found between

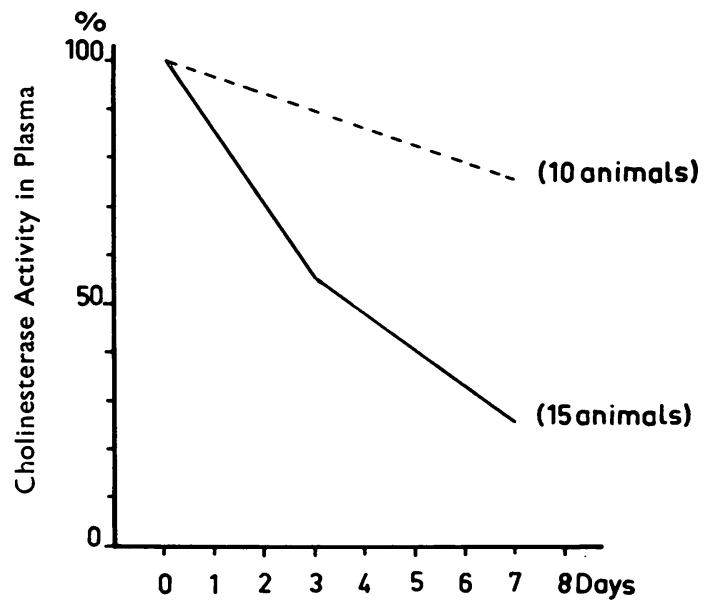

FIG. 4.-Effect on plasma cholinesterase activity (BChE) of exposure in the experimental chamber for eight hours a day and continuously at 30 to $32^{\circ} \mathrm{C}$. and 1 to 1.2 air changes per hour.

Solid line denotes animals exposed continuously, and dotted line those exposed eight hours per day. different individuals. The mean activity $(\mu 1$ $\mathrm{CO}_{2} / 30$ min.) for a group of unexposed guinea-pigs $(\mathrm{n}=156)$ was $73 \cdot 3 \pm 1 \cdot 27(\sigma=15 \cdot 8)$. The $\mathrm{BChE}$ activity of each exposed animal was recorded as a percentage of the activity before exposure.

As will be seen from Fig. 3, the animals showed a decrease of $\mathrm{BChE}$ activity which was more marked both at the higher temperature and with reduced ventilation.

Continuous exposure was compared with exposure for eight hours a day. In the latter case, as might be expected, the effect on BChE activity was less (Fig. 4).

In a few expariments with prolonged exposure it was found that after one to two weeks-the time varying somewhat with different experimental conditions-BChE activity settled at a stable level (Fig. 5). The strip in the exposure chamber was changed every week. Further experiments, continued for six weeks, gave substantially the same results. Similar results with repeated exposure of rats to sarin, another organic phosphorus compound, were obtained by Cohen, Oberst, Crook, and Harris (1956).

\section{Summary}

A field investigation showed that the use of parathion-impregnated gauze strips for fly control in cowsheds did not affect the cholinesterase activity of erythrocytes (AChE) or plasma (BChE) in the farmworkers concerned, over a period of a month. 


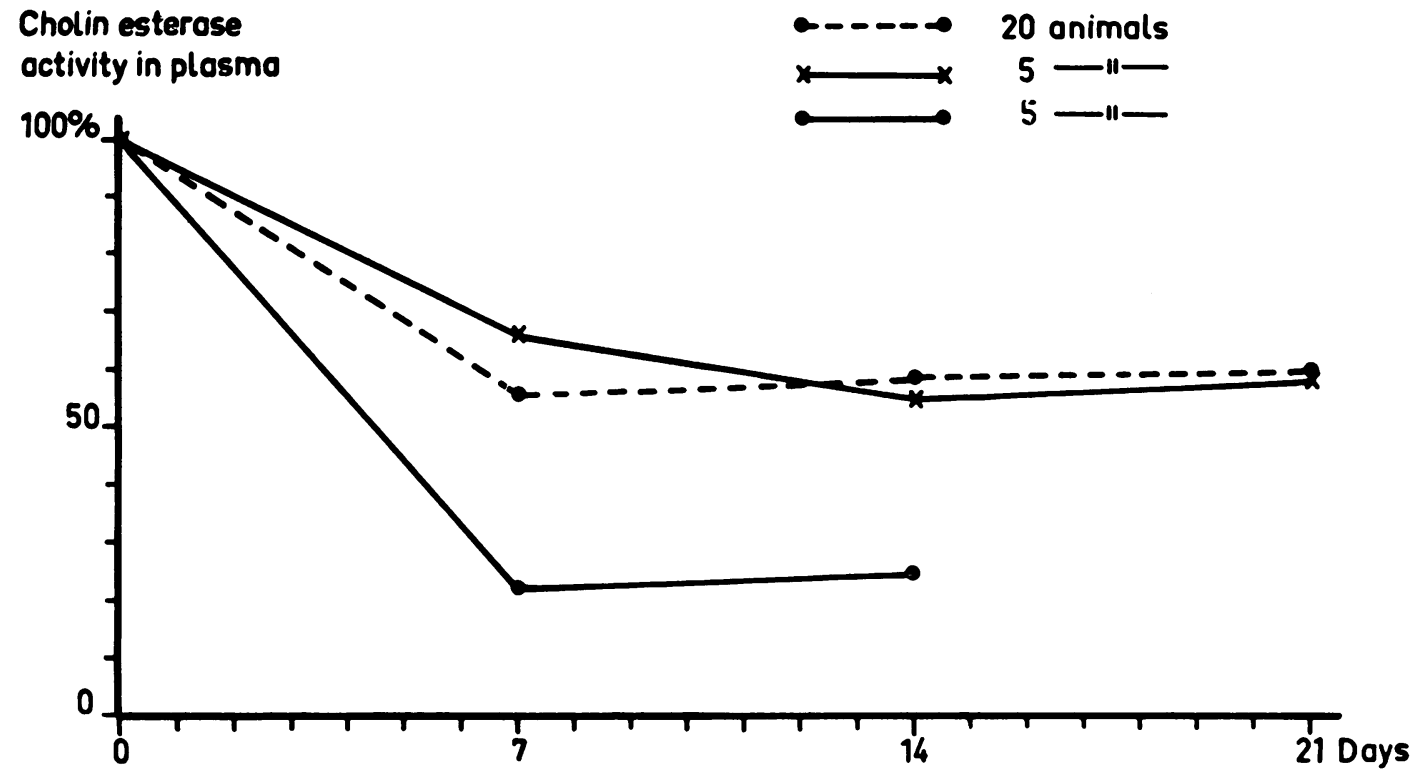

FIG. 5.-Effect on plasma cholinesterase activity (BChE) of prolonged continuous exposure. Temperature and ventilation varied in different experiments.

Laboratory experiments with guinea-pigs exposed to parathion-impregnated gauze strips at temperatures of $25^{\circ} \mathrm{C}$. and above, and with a ventilation below 2.5 air changes per hour, showed that under these adverse conditions the plasma cholinesterase (BChE) activity was reduced. Erythrocyte cholinesterase (AChE) activity, which is small in guineapigs, was not estimated. The reduction in $\mathrm{BChE}$ activity was stabilized after seven to 14 days' exposure.

\section{REFERENCES}

Augustinsson, K.-B. (1948). Acta physiol. scand., 15, Suppl. 52. (1955). Ibid., 35, 40.

- and Heimbürger, G. (1953). Ibid., 30, 45.

Barnes, J. M., and Denz, F. A. (1953). J. Path. Bact., 65, 597.

Bidstrup, P. L., Bonnell, J. A., and Beckett, A. G. (1953). Brit. med. J.,

1, 1068.

Cohen, B. S., Oberst, F. W., Crook, J. W., and Harris, C. (1956).

Durham, W. F., Gaines, T. B., and Hayes, W. J., Jr. (1956). A.H.A. Arch. industr. Hlth, 13, 326.

Fenton, J. C. B. (1955). J. Path. Bact., 69, 181

Glömme, J., and Swensson, À. (1955). Svenska LäkT., 52, 1175.

Kilpatrick, J. W., and Schoof, H. F. (1956). Publ. Hlih Rep. (Wash.), 71, 144.

Maier, P. P., and Mathis, W. (1955). Mod. Sanit., 7, April, p. 32. Wichmand, H. (1953). Nature (Lcnd.), 172, 758. 